\title{
Congress hearings used as 'scientific court'
}

Washington. George Brown, the senior Democrat on the Science Committee in the US House of Representatives, has launched a blistering attack on his Republican opponents for their conduct of congressional hearings at which well-known 'sceptics' testified on the integrity of the science associated with key environmental issues.

The three hearings, entitled "Scientific Integrity and Public Trust", dealt respectively with ozone depletion, global warming and the danger of dioxins. They were called by Dana Rohrabacher (Republican, California), chair of the committee's energy and environment subcommittee, to establish if public science agencies were biased on these issues (see Nature 387, 329; 1995).

In a 64-page report published last week, Brown argues that the hearings not only failed to find evidence for such bias but also "constituted an unprecedented assault on the peer-review system and the scientific process itself". Brown says that the hearings "repudiated peer review" by exhibiting the view "that scientific truth is more likely to be found at the fringes of science rather than at the centre". He accuses Rohrabacher of seeking to set up "a scientific court where the subcommittee would determine scientific truth through testimony and questions".

Rohrabacher hit back quickly at Brown's allegations. "It is the very fairness of these hearings that infuriated the left-wing ideologues" among Brown's staff, he said in a statement. "After 40 years of autocratic, one-party rule, they are horrified that diverse points of view within the scientific community have been given a fair hearing, with panels of witnesses equally divided.'

The hearings, which took place late last year, gave a platform to well-known 'sceptics' such as Sallie Baliunas of Harvard University and Fred Singer, an emeritus professor of the University of Virginia, who testified against the prevailing scientific con-

\section{Maths gaffe may add}

Washington. George Brown (Democrat, California), a leading science advocate in the US Congress (see above), has come under heavy fire from his Republican opponent, Linda Wilde, after a television debate faux pas which could affect his success in defending a wafer-thin majority in his San Bernardino district.

At one point in the debate, the congressman said that he imagined that Wilde, "because she is a lady, is afraid of math". His opponent, whose father is a mathematician, subsequently went after Brown demanding further apologies - Brown had already apologised, before the debate was over - and using it to portray the 76-year-old liberal congress-

sensus on ozone depletion. Patrick Michaels, also of the University of Virginia, criticized prominent scientists holding mainstream views on global warming.

Brown argues that neither Baliunas nor Singer has published any recent peerreviewed research on ozone depletion. His report also says that the 'sceptics' were unable to substantiate their most serious

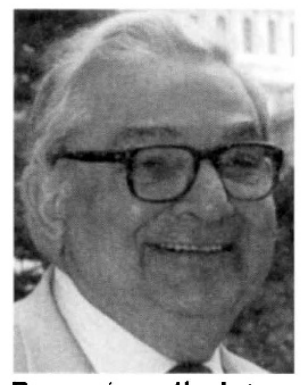

Brown: 'sceptics' gave no evidence of bias. charge, namely that science agencies and the scientific process were systematically excluding their views from consideration.

Baliunas testified at the ozone hearing that she had been told "by officers of federal funding agencies" not to apply for funds "on certain questions" because "answering these questions would undermine the possibility of getting new funds" and "might deter policy-makers from 'doing the right thing"'.

The report says that Baliunas was asked to name the officials in question and to provide information to back up this allegation, but declined to do so because of a fear of legal liability. In correspondence with the committee, however, Baliunas alleged that some of her work had been rejected for publication in Nature on political grounds. In response to an inquiry from Brown, John Maddox, then editor of Nature, said that the decision to reject Baliunas's paper was "made on purely technical grounds, which the authors had never chosen to rebut".

Brown says that the hearings "failed to produce credible substantiation for any of these claims of scientific misconduct" but instead "showed science being conducted in an objective and apolitical manner, consis-

\section{up to negative votes}

\section{man as sexist and out-of-touch.}

Brown later characterized his comment as a "misstatement", saying that he had been trying to underline the need encourage school teachers to overcome false stereotypes - such as the idea that girls shouldn't do mathematics. "My record on women's issues speaks for itself," he says.

In next week's election, Brown, a leading congressional liberal, is defending a district which he has held for sixteen consecutive terms in the face of demographic changes that make it look increasingly like Republican territory. "George is not good at telling jokes," sighs one of his campaign staff. C. $\mathbf{M}$. tent with the traditional norms of scientific integrity". He calls on the scientific community to do more to counter publicly the positions of the sceptics.

But Rohrabacher's staff insist that the hearings were successful in highlighting the question of how agencies such as the Environmental Protection Agency conduct their peer review of science. According to one Republican staff member, governmentfunded scientists remain scared to testify against mainstream positions on such questions as the man-made nature of global warming.

Asked to comment on the report, Singer said that he had repeatedly published peerreviewed research on ozone, and described the report as "a campaign to smear people". Michaels said: "I don't think I've ever seen scientists attacked so vehemently by people in Congress for their beliefs." He said that the report was "an attempt to chill debate".

Colin Macilwain

\section{Berlin's universities face further cuts}

Munich. Berlin's three universities reacted angrily last week to the city government's decision to cut their combined budget by DM150 million (US\$231 million) in the next five years, on top of the cut of DM600 million (\$924 million) imposed since 1993.

The government wants to reduce the universities' costs to DM2 billion by 2001 (see Nature 369, 431; 1994). Peter Radunski, Berlin's minister for science, believes that the cuts will be very damaging. He accepts the new cut, which has been caused by the city's near bankruptcy, with bad grace. "We have no choice," he says.

After years of battling with each other, the Humboldt, Free and Technical Universities have recently begun cooperating to find ways of coping with the funding crisis. Over the summer, as it became clear that new cuts were likely, they told Radunski that they would accept a reduction of DM50 million in return for an assurance of no further cuts before 2001 .

The proposed agreement also included compromises on some controversial issues - for example, the universities would introduce entrance examinations and streamline their administrations.

Radunski now wants to offer the universities a less favourable deal: no cuts for four years in exchange for the DM150-million cut imposed last week. But the universities may not be ready to negotiate with him. Dieter Schumann, president of the Technical University, says: "The common basis for a contract has been destroyed because the new plans will be our ruin."

Quirin Schiermeier 